\title{
MURAL DI LINGKUNGAN SEKOLAH DALAM KONTEKS PENDIDIKAN KONSERVASI
}

\author{
Suherman $^{1 凶}{ }^{\text {Sunarto }}{ }^{2}$, Sri Prastiti Kusuma Anggraeni ${ }^{3}$ \\ ${ }^{1}$ Program Studi PGSD STKIP Muhammadiyah Enrekang, Sulawesi Selatan \\ ${ }^{2}$ Jurusan Pendidikan Sendratasik, Fakultas Bahasa dan Seni, Universitas Negeri Semarang \\ ${ }^{3}$ Jurusan Pendidikan Bahasa Jawa, Fakultas Bahasa dan Seni, Universitas Negeri Semarang \\ Email: suhermankasumba@gmail.com; sunartounnes@gmail.com; dewipraswida4@gmail.com
}

\begin{tabular}{ll}
\hline Info Artikel & Abstract \\
\cline { 2 - 3 } $\begin{array}{l}\text { Sejarah Artikel: } \\
\text { Diterima 13 April } 2019 \\
\text { Direvisi 15 April } 2019 \\
\text { Disetujui 1 Juni } 2019\end{array}$ & $\begin{array}{l}\text { The task of education in general is to deliver, to create quality individuals or learners, to } \\
\text { be noble in character, and to be dedicated to the nation and people. In the world of formal } \\
\text { education, it is known as conservation education, namely education programs that instill } \\
\text { and preserve socio-cultural values (justice) which are considered as guidelines for humans } \\
\text { as individuals who live in a social group. Conservation education in its latest development } \\
\text { is no longer only done in the classroom orally and in writing, but the visual learning model } \\
\text { outside the classroom has also been practiced. Mural in the context of conservation } \\
\text { Keywords: }\end{array}$ \\
\hline $\begin{array}{l}\text { Conservation Education, in schools has an active role as a medium of learning with visual methods to } \\
\text { Murals, Socio-Cultural Values }\end{array}$ & $\begin{array}{l}\text { improve students' understanding and knowledge of socio-cultural values. } \\
\text { Abstrak }\end{array}$ \\
\hline $\begin{array}{l}\text { Tugas pendidikan secara umum adalah mengantar, hingga menciptakan individu atau } \\
\text { peserta didik yang berkualitas, berbudipekerti luhur, serta berbakti terhadap nusa dan } \\
\text { bangsa. Dalam dunia pendidikan formal, dikenal adanya pendidikan konservasi, yaitu } \\
\text { program pendidikan yang menanamkan dan melestarikan nilai-nilai sosial-budaya } \\
\text { (adiluhung) yang dianggap sebagai pedoman bagi manusia sebagai individu yang hidup } \\
\text { dalam suatu kelompok sosial masyarakat. Pendidikan konservasi dalam perkembangan } \\
\text { mutakhirnya, bukan lagi hanya dilakukan di dalam ruang kelas secara lisan dan tulisan, } \\
\text { akan tetapi model pembelajaran dengan metode visual di luar kelas pun telah dipraktikkan. } \\
\text { Mural dalam konteks pendidikan konservasi di sekolah memiliki peran aktif sebagai media } \\
\text { pembelajaran dengan metode visual untuk meningkatkan pemahaman dan pengetahuan } \\
\text { peserta didik tentang nilai-nilai sosial-budaya. }\end{array}$
\end{tabular}

(C) 2019 Universitas Muria Kudus 


\section{PENDAHULUAN}

Pendidikan dalam telaah filosofis telah dipandang sebagai suatu hal yang penting dalam menunjang serta menuntun keberlangsungan hidup manusia di segala penjuru dunia. Kepercayaan ini telah mengalir dan menjelma dalam kehidupan manusia sebagai makhluk berbudaya, dari waktu ke waktu, sampai saat ini. Sebagai contoh, di dunia Barat praktik-praktik pendidikan muncul sebagai manifestasi dari kepercayaan terhadap pendidikan, seperti school, atau pedagogie, education, andragogie, dan lain sebagainya. Sementara di Timur sendiri, hal demikian dapat pula ditemukan dengan berbagai istilah, seperti: madrasah, majlis ta'lim, halaqah, pesantren, padepokan, grahavidya, dan masih banyak diantaranya, yang kesemuanya merujuk pada wahana pendidikan.

Perumusan-perumusan mengenai hakiki pendidikan dalam perkembangan peradaban pun telah dan banyak menjadi bahan pemikiran para kaum-kaum intelektual. John Dewey (18591952) misalnya, sebagai Salah satu filsuf Amerika, merumuskan pendidikan sebagai proses pembentukan kecakapan mendasar secara intelektual dan emosional sesama manusia (Gandhi HW, 2011:65). Dalam hal ini tentunya harus didasarkan pada "pengalaman" sebagai kuncinya (Dewey, 2004:89; Sunarto, 2016). Di sisi lain, Paulo Freire (2007:ix), sebagai tokoh pendidikan terkemuka pada paroh abad ke-20, mengatakan bahwa pendidikan merupakan proses memanusiakan manusia (humanisasi), yaitu berorientasi kepada pengenalan manusia dan dirinya sendiri. Kemudian di Indonesia sendiri, tokoh pendidikan, Ki Hadjar Dewantara (1977:14), mengatakan bahwa pendidikan merupakan daya-upaya untuk memajukan bertumbunya budipekerti (kekuatan batin, karakter), pikiran (intelek), dan tubuh anak (manusia).

Kemajuan suatu bangsa dan negara sangat ditentukan oleh kualitas serta mutu pendidikannya. Negara yang mampu memanfaatkan pendidikan sebagai jalur untuk mengembangkan sumber daya manusia, yaitu dengan mengelola dan menata secara efektif sistem pendidikannya, maka suatu keniscayaan akan tercapainya apa yang dicita-citakan, yaitu bangsa dan negara yang "ideal". Sekiranya, inilah yang ingin direalisasikan oleh tokoh-tokoh pendidik Indonesia, yang kemudian merumuskan suatu tujuan pendidikan nasional, sebagaimana termaktub dalam Undang-Undang No. 20 tahun
2003 tentang Sistem Pendidikan Nasional, pasal 3, yaitu: mengembangkan potensi peserta didik agar menjadi manusia yang beriman dan bertakwa kepada Tuhan Yang Maha Esa, berakhlak mulia, sehat, berilmu, cakap, kreatif, mandiri, dan menjadi warga negara yang demokratis serta bertanggung jawab.

Sebagaimana diketahui bahwa bangsa Indonesia telah mendeklarasikan kemerdekaannya sejak tahun 1945 oleh para pelopor kemerdekaan, sehingga ini menjadi suatu pekerjaan rumah yang dititipkan mereka sebagai pelopor kepada generasi penerus untuk melanjutkan apa yang dicita-citakan, yaitu bangsa Indonesia yang merdeka, bersatu, berdaulat, adil, dan makmur. Akan tetapi, apa yang kita saksikan pada realitas sosial budaya masyarakat Indonesia kini, di mana sudah banyak muncul ketimpangan sosial, krisis nilai di segala bidang, dekadensi moral yang semakin tampak, sehingga bangsa Indonesia semakin jauh dari apa yang sebelumnya dicita-citakan.

Sebagai calon generasi penerus bangsa, sekiranya nilai-nilai sosial budaya seharusnya sudah sejak dini ditanamkan pada anak, agar kelak dapat tercipta generasi-generasi yang cakap, mapan, demokratis, serta dapat bekerja sesuai dengan tugas dan tanggungjawabnya sebagai individu yang hidup dalam suatu kelompok masyarakat. Demikian, maka jelas bahwa tugas pendidikan secara umum adalah bagaimana mengantar, hingga menciptakan individu-individu atau peserta didik yang berkualitas, berbudipekerti luhur, demokratis, dan tentunya berbakti terhadap nusa dan bangsa. Akan tetapi, khususnya dalam dunia pendidikan formal di mana pada beberapa tahun terakhir, justru malah memperlihatkan sesuatu yang sangat kontradiktif dengan tujuan pendidikan itu sendiri. Terutama pada wilayah pendidikan moral/akhlak yang sudah nyaris tidak menunjukkan taringnya lagi.

Nilai moral atau sering disebut sebagai etika, tentunya merupakan salah satu bagian terpenting dalam projek pembangunan sumber daya manusia. Krisis nilai moral atau krisis moralitas akan berdampak pada sistem tatanan kehidupan manusia. Salah satu penyebab munculnya ketimpangan-ketimpangan sosial, oleh karena masyarakat telah mengalami krisis moralitas, manifestasi dari krisis kesadaran (Suherman, 2016:18). Sebagai contoh kongkrit, khususnya di Indonesia, sudah sering ditemukan peserta didik (siswa) yang berani melawan dan 
Suherman, S., Sunarto, S., dan Anggraeni, Sri Prastiti Kusuma

MURAL DI LINGKUNGAN SEKOLAH DALAM KONTEKS PENDIDIKAN KONSERVASI

REFLEKSI EDUKATIKA : Jurnal Ilmiah Kependidikan, Volume 9, Nomor 2, Juni 2019, hlm 192-203

bahkan ada yang sampai memukul gurunya dengan alasan yang tidak jelas. Seolah-olah tidak ada lagi batasan yang tepat untuk diterangkan mengenai hukum yang berlaku bagi peserta didik. Demikian, maka wajar saja ketika Kesuma, dkk. (2011:2) mengatakan bahwa kondisi moral/akhlak generasi muda kita telah rusak dan hancur.

Hal ini kemudian menjadi bahan perenungan khususnya bagi para pendidik yang berlatar belakang seni (pendidikan seni) untuk merumuskan suatu konsep dalam rangka menangani kasus yang menimpa dunia anak muda seperti diterangkan di awal. Dalah hal ini, Pendidikan Seni sebagaimana merupakan salah satu program pendidikan yang menggunakan seni sebagai sarana pendidikan (Soehardjo, 2012:13), mencoba menawarkan solusi, yaitu dengan melalui mural (lukisan dinding) di sekolah-sekolah. Sekiranya, konsep Pendidikan Seni ini merupakan salah satu wacana konservasi dalam proses pendidikan, atau yang sering disebut sebagai pendidikan konservasi.

\section{ANTARA KONSERVASI, ILMU PENGETAHUAN, DAN PENDIDIKAN}

Istilah konservasi dalam Kamus Besar Bahasa Indonesia (KBBI) diartikan sebagai pemeliharaan dan perlindungan sesuatu secara teratur untuk mencegah kerusakan dan kemusnahan dengan jalan mengawetkan; pengawetan; pelestarian. Ketika merujuk pada penjelasan tersebut, maka konservasi dapat diartikan sebagai upaya pelestarian sumber daya yang berfokus pada sumber daya alam. Konsep atau wacana konservasi semacam ini, sebenarnya sangat sempit cakupannya karena hanya berkaitan dengan dunia luar manusia. Oleh karena itu, di sini pembahasan tentang konsep konservasi akan dilihat dari prespektif yang lebih luas dan kompleks, terutama mengenai bagaimana cakupannya dalam dunia pendidikan.

Konservasi sebagai suatu proses kompleks dan terus-menerus melibatkan penentuan mengenai apa yang dipandang sebagai warisan, bagaimana ia dijaga, bagaimana ia digunakan, oleh siapa, dan untuk siapa. Warisan yang dimaksud di sini tidak hanya menyangkut hal yang bersifat fisik, tetapi menyangkut seluruh aspek kebudayaan. Dengan demikian, konservasi tidak hanya sekedar persoalan perawatan, pelestarian, dan perlindungan alam, tetapi juga menyentuh persoalan pelestarian warisan kebudayaan dan peradaban umat manusia (Richmond, dkk, 2009:xiv; Yuniawan, dkk, 2014:42).

Terkait tentang konservasi, dalam dunia pendidikan dikenal adanya paradigma pendidikan konservatif yang berkembang secara luas, yang kemudian juga dirumuskan sebagai salah satu ideologi pendidikan. Kaum konservatif dalam hal ini melihat betapa pentingnya harmoni dalam masyarakat dan menghindarkan konflik dan kontradiksi (O’neil, 2008:xii). Pendidikan konservatif ini muncul sebagai reaksi atas pendidikan modern yang liberal, yang dianggap keliru dalam mengatasi persoalan-persoalan sosio-kultural. Dalam tulisannya, William F. Buckley (2015:152), mengatakan:

Kaum konservatif jijik menyaksikan hasil-hasil pendidikan modern yang liberal; mereka bersimpati dengan kebutuhan-kebutuhan pendidikan individual seorang anak; memahami eksistensi kerohanian eksistensi manusia; sangat peduli pada bangsa dan budaya secara patriotis... Tantangan terbesar bagi kita adalah memulihkan prinsip-prinsip - prinsipprinsip yang benar; yang telah dilecehkan, dianiaya, dicampakkan oleh liberalism; yang telah mereka ganti dengan 'prinsip-prinsip baru' yang tak lain hanya batang tubuh metodologis.

Pendidikan liberal merupakan pendidikan yang menjadikan Positivisme sebagai salah satu dasar bagi model pendidikannya, sekligus sebagai paradigma ilmu sosial-humaniora yang dominan. Positivisme sendiri, pernah dikritik oleh salah penganut teori kritis, Jurgen Habermas, dengan menjelaskan tiga kategori pengetahuan, yaitu; pertama, apa yang disebutnya sebagai instrumental knowledge (pengetahuan instrumental), di mana tugas dan tujuan pengetahuan adalah untuk mengontrol, memprediksi, memanipulasi dan eksploitasi objeknya; kedua, hermeneutic knowledge (pengetahuan hermeneutik), di mana tugas pengetahuan yaitu untuk memahami; kemudian yang ketiga adalah critical knowledge (pengetahuan kritis) atau emancipatory knowledge (pengetahuan emansipatoris), yaitu suatu pendekatan yang dengan kedua pendekatan 
Suherman, S., Sunarto, S., dan Anggraeni, Sri Prastiti Kusuma

MURAL DI LINGKUNGAN SEKOLAH DALAM KONTEKS PENDIDIKAN KONSERVASI

REFLEKSI EDUKATIKA : Jurnal Ilmiah Kependidikan, Volume 9, Nomor 2, Juni 2019, hlm 192-203

sebelumnya, di mana pendekatan ini menempatkan ilmu pengetahuan sebagai katarsis untuk membebaskan manusia (O’Neil, 2008:xvxvi).

Sekilas mengenai Positivisme, memang merupakan suatu paradigma yang tidak sedikit mendapat kritikan. Horkheimr, Adorno, dan Marcuse (para penganut teori kritis generasi pertama), misalnya, yang menunjukkan bahwa apa yang dikatakan Positivisme itu bermasalah, karena pandangan tentang metode penerapan ilmu-ilmu alam (Naturewissenchaften) pada ilmu-ilmu sosial-humaniora (Geisteswissenchaften) tak lain dari saintisme dan ideologi. Kritik-kritik mereka pun kala itu masih sangat-sangat berbau moralitas, hingga pada puncaknya persoalan ini ditunjukkan secara epistemologis oleh Habermas (Hardiman, 2003:24). Selain itu, masih banyak diantara kaum intelektual yang melancarkan kritiknya terhadap paradigma ini. Demikian, karena Positivisme mengangap bahwa ilmu itu bebas dari nilai-nilai yang melatarbelakanginya, sehingga paham yang mengagung-agungkan Positivisme melihat sebelah mata Geisteswissenchaften (Sunarto, 2016:112). Oleh karena itu, pada kasus seperti ini manusia sebagai satu kesatuan dari kosmos akan mengambil jarak dan memiliki hasrat yang meluap untuk menguasai alam sepenuhnya, serta mereduksi pengetahuan tentang ilmu-ilmu sosialhumaniora secara universal ke dalam teknismetodologis belaka.

Adapun konservatisme dalam dunia pendidikan secara umum, sebagaimana bagi kaum konservatif menganggap bahwa tujuan atau sasaran pendidikan adalah sebagai pelestarian dan penerusan pola-pola kemapanan sosial, pola-pola perilaku sosial konvensional, serta tradisi-tradisi, dengan ciri-cirinya yang khas, yaitu: 1) Menganggap bahwa nilai dasar pengetahuan ada pada kegunaan sosialnya; 2) Menekankan peran manusia sebagai warga negara; manusia dalam perannya sebagai anggota sebuah negara yang mapan; 3) Menekankan penyesuaian diri yang bernalar; menyadarkan diri pada jawaban-jawaban terbaik dari masa silam sebagai tuntutan yang paling bisa dipercaya untuk memandu tindakan dimasa kini; 4) Memandang pendidikan sebagai sebuah pembelajaran (sosialisasi) nilai-nilai sistem yang mapan; 5) Memusatkan perhatian pada tradisitradisi dan lembaga-lembaga sosial yang ada; 6)
Menekankan stabilitas budaya melebihi kebutuhan akan perombakan budaya, dan hanya menerima perubahan-perubahan yang pada dasarnya cocok dengan tatanan sosial yang sudah mapan; 7) Berdasarkan sebuah sitem budaya tertutup (etnosentrisme); 8) Mengakar pada kepastian-kepastian yang sudah teruji oleh waktu; dan, 9) Menganggap bahwa wewenang intelektual tertinggi adalah budaya dominan dengan segenap sistem keyakinan dan perilaku yang mapan (O'neil, 2008:336-337).

Atas dasar pemikiran tersebut, kemudian menjadi suatu dorongan untuk memunculkan suatu paradigma baru dalam dunia pendidikan, yaitu pendidikan konservatif. Demikian, maka pendidikan konservasi dianggap sebagai jalan keluar atas kasus yang melanda dunia pendidikan dewasa ini. Pendidikan konservasi, sebagaimana penerapan konsep konservasi sebagai metodologi yang digunakan dalam pendidikan, dengan kata lain konsep konservasi menjadi paradigm dan segaligus sarana, serta menjadi suatu ideologi khusunya dalam praktik-praktik pendidikan.

\section{GAMBARAN UMUM PENDIDIKAN KONSERVASI}

Dalam Kondisi dan Berita Biodiversitas Indonesia (2015), diterangkan bahwa pendidikan konservasi adalah program yang bertujuan untuk memberikan pengetahuan kepada banyak orang agar lebih sadar dan lebih perhatian dalam melestarikan lingkungan dan peduli melindungi dan memanfaatkan sumber daya hayati secara bijaksana dan berkelanjutan. Melestarikan sumber daya memang pada dasarnya merupakan kebutuhan dan kewajiban bagi tiap warga negara. Itulah sebabnya, pendidikan secara formal maupun non-formal harus mengandung nilainilai dalam empat pilar pendidikan, yaitu; belajar untuk tahu, belajar untuk berbuat, belajar untuk memahami diri sendiri (jati diri), dan belajar untuk hidup bersama dan saling menghargai atas dasar kesetaraan dan toleransi dalam masyarakat.

Sebagai salah satu perguruan tinggi di Jawa Tengah, Pada tanggal 12 Maret 2012, Universitas Negeri Semarang (Unnes) dideklarasikan sebagai Universitas Konservasi, dengan tujuh pilar konservasi, yaitu: 1) biodiversitas, 2) arsitektur hijau \& transportasi internal, 3) pengolahan limbah, 4) nirkertas, 5) energi bersih, 6) etika, seni dan budaya, dan 7) kader konservasi (Masrukhi, dkk, 2010:3; Yuniawan, dkk, 2014:42). Upaya mewujudkan 
Suherman, S., Sunarto, S., dan Anggraeni, Sri Prastiti Kusuma

MURAL DI LINGKUNGAN SEKOLAH DALAM KONTEKS PENDIDIKAN KONSERVASI

REFLEKSI EDUKATIKA : Jurnal Ilmiah Kependidikan, Volume 9, Nomor 2, Juni 2019, hlm 192-203

Unnes menjadi Universitas Konservasi sesungguhnya tidak lepas dari landasan yang bersifat filosofis, yaitu alam semesta seisinya adalah ciptaan dan anugerah dari Tuhan Yang Maha Esa, dan dengan demikian alam memiliki cara sendiri untuk mengatur keseimbangan pada dirinya. Sayangnya, perkembangan peradaban yang tidak bermoral menyebabkan kerusakan tataan alam yang ada.

Menurut Wahyudin dan Sugiharto (Yuniawan, dkk, 2014:42), Universitas Konservasi adalah sebuah universitas yang dalam pelaksanaan tridharma perguruan tinggi mengacu pada (perlindungan, pengawetan, dan pemanfaatan secara lestari) sumber daya alam dan seni budaya serta berwawasan ramah lingkungan. Dalam naskah akademik ditegaskan bahwa Universitas Konservasi memiliki tujuan yang akan dicapai sarat muatan nilai yang sangat luhur dan universal. Dengan demikian, perubahan timbal balik antara lingkungan dan bahasa dipelajari melalui kajian ekolinguistik. Kajian ekolinguistik mengkaji ekosistem yang merupakan bagian dari sistem kehidupan manusia (ekologi) dengan bahasa yang dipakai manusia dalam berkomunikasi dalam lingkungannya (linguistik). Artinya, sikap mahasiswa terhadap ungkapan-ungkapan pelestarian lingkungan di kampus konservasi akan mempengaruhi perilaku pribadi maupun komunitas mahasiswa dalam berkonservasi.

Sebagaimana cakupan tentang konsep konservasi yang sangat luas, yang juga erat kaitannya dengan dimensi-dimensi intrinsik kemanusiaan, baik itu berupa moral religi maupun sosial-budaya secara keseluruhan, maka konservasi merupakan sebuah upaya untuk menjaga, melestarikan, dan menerima perubahan dan/atau pembangunan. Perubahan yang dimaksud bukanlah perubahan yang terjadi secara drastis dan serta-merta, melainkan perubahan secara alami yang terseleksi. Hal tersebut bertujuan untuk tetap memelihara identitas dan sumber daya lingkungan, serta mengembangkan beberapa aspeknya untuk memenuhi kebutuhan arus modernitas dan kaulitas hidup yang lebih baik. Dengan demikian, dalam konsep konservasi terdapat alur memperbaharui kembali (renew), memanfaatkan kembali (reuse), mengurangi (reduce), mendaurulang kembali (recycle), dan menguangkan kembali (refund) (Rachman, 2012:32).
Lebih lanjut, Maman Rachman (2012) dalam artikelnya Konservasi Nilai dan Warisan Budaya, mengatakan bahwa berdasarkan cakupan konservasi yang luas, maka paling tidak, terdapat empat nilai yang terkandung dalam konsep konservasi, antara lain: menanam, memanfaatkan, melestarikan dan mempelajari. Nilai-nilai tersebut bersifat hirarkis, spiral, dan berkesinambungan. Menanam, dapat dimaknai dalam dua arti, yaitu: pertama, secara fisik, di mana menanam dapat diartikan menancapkan sebuah benih atau bibit ke dalam tanah dengan harapan memperoleh hasil dari bibit/benih yang ditanam. Namun demikian, hasil yang diharapkan sudah barang tentu tidak serta merta berhasil tanpa ada upaya melindungi, merawat, dan memelihara; kemudian yang kedua, yaitu secara non fisik, di mana menanam dapat diartikan meletakkan nilai-nilai fundamental dan luhur yang telah mengkristal menjadi pedoman atau pandangan hidup dan dasar negara. Nilainilai luhur tersebut berawal dan berasal dari nilai-nilai luhur yang disepakati oleh rakyat penduduk wilayah tertentu, kemudian meluas dan disepakati oleh masyarakat dan bangsa. Lebih lanjut, dari makna menanam baik fisik maupun non fisik dapat diwujudkan dalam nilainilai konkret yang luhur berupa budaya yang adiluhung.

Dengan merujuk paradigma pendidkan konservasi seperti yang telah diuraikan di atas, dapat diterangkan bahwa pendidikan konservasi merupakan pendidikan yang menanamkan dan melestarikan nilai-nilai adiluhung yang dianggap sebagai pedoman bagi manusia sebagai makhluk individu yang hidup dalam suatu kelompok sosial masyarakat. Oleh karena itu, pendidikan konservasi sejatinya merupakan suatu program pendidikan yang mampu menciptakan peserta didik yang menjunjung tinggi nilai-nilai sosialbudaya, untuk mencapai suatu tatanan hidup yang ideal.

\section{TENTANG MURAL PERKEMBANGANNYA}

Mike Susanto (2011:286) dalam bukunya Diksirupa, mendefinisikan mural yang berasal dari kata 'murus' (tembok) sebagai lukisan besar yang dibuat untuk mendukung ruang arsitektur. Lebih lanjut Susanto bahwa, mural merupakan lukisan yang dibuat secara langsung maupun tidak langsung pada permukaan dinding suatu bangunan, yang tidak langsung memiliki 
Suherman, S., Sunarto, S., dan Anggraeni, Sri Prastiti Kusuma MURAL DI LINGKUNGAN SEKOLAH DALAM KONTEKS PENDIDIKAN KONSERVASI REFLEKSI EDUKATIKA : Jurnal Ilmiah Kependidikan, Volume 9, Nomor 2, Juni 2019, hlm 192-203

kesamaan dengan lukisan atau sejenis dengan istilah fresko. Perbedaannya terletak pada persyaratan khusus yang harus dipenuhi oleh lukisan dinding; keterkaitannya dengan arsitektur/bangunan, baik dari segi desain, maupun usia serta perawatan dan juga dari segi kenyamanan pengamatannya.

Mengenai mural (lukisan dinding) sebenarnya bukanlah suatu hal yang baru. Hal tersebut dapat dilacak dari jejak-jejak peradaban manusia yang hidup pada zaman pra-sejarah, atau yang sering disebut sebagai zaman primitif. Manusia pada zaman pra-sejarah kerap melakukan ritual dalam rangka berkomunikasi dengan Yang Transenden yang diyakininya, atau sekedar mengungkapkan perasaannya, dengan metode "visual". Asumsi ini diperkuat oleh beberapa anggapan yang menyatakan bahwa mural sudah dimulai sejak 30.000 tahun yang lalu, di mana sejumlah gambar atau lukisan prasejarah banyak ditemukan pada dinding-dinding gua.

Di Indonesia misalnya, ditemukan lukisan-lukisan cap tangan dan binatang di dinding gua Leang-Leang, Maros, Sulawesi Selatan, yang kemudian kerap disebut sebagai bentuk mural generasi pertama. Selain itu, banyak pula ditemukan pada dinding-dinding gua di Altamira Spanyol dan Lascaux Prancis, yang melukiskan aksi-aksi berburu, meramu, dan aktivitas religius. Lukisan dinding pada zaman pra-sejarah seperti ini, paling banyak ditemukan di Prancis, yaitu sekitar 150 tempat, kemudian di Spanyol ada 128 tempat, dan di Italia lukisan dinding ditemukan di 21 tempat (Wicandra, 2005:128).

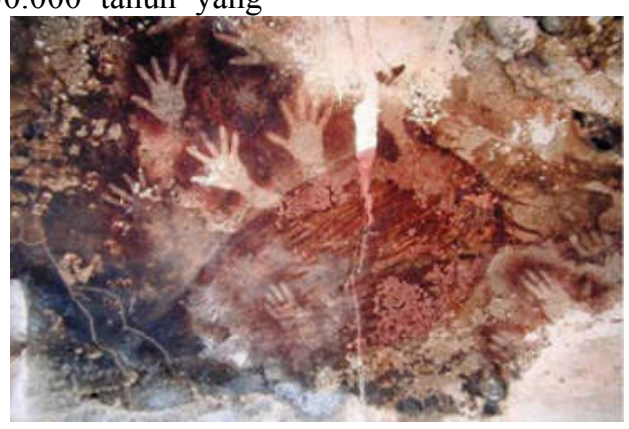

Gambar1. Lukisan pada dinding gua Leang-Leang, Maros, Sulawesi Selatan

Sumber: https://www.makassarguide.com/2014/09/taman-prasejarah-leang-leang.html, diakses 2109.

Dalam perkembangan selanjutnya mural pun semakin menampakkan diri, di mana pada masa Renaissance sekitar abad ke-15 sampai abad ke-16, muncul para seniman-seniman mural seperti Cimabue, Giotto, dan Ghirlandiao.
Sementara pada abad 20-an, muncul seniman mural terkemuka di Mexico seperti Diego Rivera, Jose Orozco dan David Alvaro sebagai (Susanto, 2011:268).

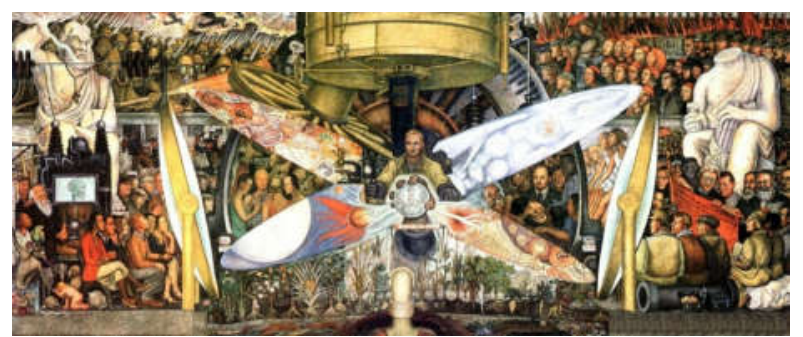

Gambar 2. Man at the Crossroads (1934) karya Diego Rivera Sumber: https://www.diegorivera.org/man-at-the-crossroads.jsp, diakses 2019. 
Suherman, S., Sunarto, S., dan Anggraeni, Sri Prastiti Kusuma

MURAL DI LINGKUNGAN SEKOLAH DALAM KONTEKS PENDIDIKAN KONSERVASI

REFLEKSI EDUKATIKA : Jurnal Ilmiah Kependidikan, Volume 9, Nomor 2, Juni 2019, hlm 192-203

Kemudian, pada tahun 1970-1990 mural memperhatikan eksistensinya dalam Jan-Mikel Basquiat dengan grafitinya di sudut-sudut keta New York dengan tulisan S.A.M.O sebagai identitasnya. Hal ini kemudian banyak

menginspirasi seniman lain untuk berkarya di ruang publik, seperti Keith Haring yang kemudian banyak mengerjakan mural dan dianggap sebagai seniman mural sepanjang karirnya (Wicandra, 2005:128).

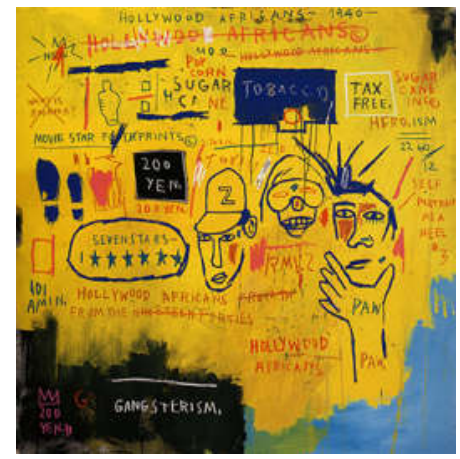

Gambar 3. Hollywood Africans (1983) karya Jan-Michel Basquiat

Sumber: http://www.jean-michel-basquiat.org/hollywood-africans/, diakses 2019.

Sebelumnya, ketika melirik pada munculnya berbagai gerakan budaya pada era '60-an' di Barat, seperti gerakan anak muda, gerakan feminisme, gerakan subkultur (hippes, punk, dan sebagainya), gerakan komunal, gerakan lingkungan dapat dilihat dalam kerangka bangkitnya 'narasi-narasi kecil' sebagaimana yang dikatakan Lyotard (Piliang, 2002:10; Wicandra, 2005:132). Gerakan-gerakan ini, muncul sebagai reaksi atau penolakan terhadap berbagai kemapanan, otoritas, dan kekuasaan yang membentuk masyarakat sebelumnya. Gerakan 'narasi-narasi kecil' merupakan suatu upaya untuk mendefinisikan kembali 'ideologi' sebagai bingkai pembentuk identitas individu dan masyarakat dalam bentuknya yang baru.

Khususnya di Indonesia, perkembangan mural (modern) sudah ada dan marak sejak zaman kemerdekaan, di mana saat itu para pejuang mengekspresikan keinginannya melalui grafity, walaupun dengan skill dan peralatan yang masih sangat sederhana, konsep tulisan di dinding menjadi paling efektif untuk mengekspresikan pendapat secara diam-diam (Luthfi, 2014).

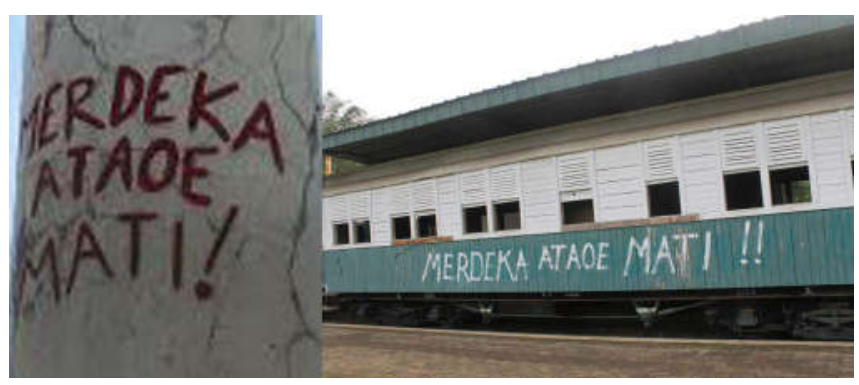

Gambar 4. Grafity Merdeka Ataoe Mati di zaman kemerdekaan Indonesia Sumber: Muhammad Luthfi, diakses 2019.

Adapun mural (lukisan dinding), tidak hanya berdiri sendiri tanpa kehadiran ribuan makna.

Bagi 
Suherman, S., Sunarto, S., dan Anggraeni, Sri Prastiti Kusuma

MURAL DI LINGKUNGAN SEKOLAH DALAM KONTEKS PENDIDIKAN KONSERVASI

REFLEKSI EDUKATIKA : Jurnal Ilmiah Kependidikan, Volume 9, Nomor 2, Juni 2019, hlm 192-203

seniman mural, ada pesan-pesan yang ingin disampaikan melalui karya-karyanya. Selain sebagai media ekspresi estetik, mural juga dapat hadir sebagai sebagai media komunikasi, serta dapat juga sebagai representasi atas kondisi-kondisi sosial-budaya, politik, ekonomi dantermasuk pendidikan.

Demikian, hingga saat ini mural telah dan banyak ditemukan di berbagai kota di seluruh dunia. Tak terkecuali di Indonesia, di mana mural telah banyak mengisi sudut-sudut kota, seperti di Yogyakarta, Makassar, dan masih banyak kota-kota besar lainnya. Bahkan pada perkembangan mutakhirnya, mural pun sudah masuk dalam lingkungan sekolah, seperti TK, SD, hingga SMP dan SMA, dengan tujuan sebagai media komunikasi bagi para peserta didik, berupa pesan-pesan moral, hingga nilainilai keyakinan adat bersama, dengan tetap menekankan dimensi-dimensi estetiknya.

\section{PENDIDIKAN KONSERVASI MELALUI MURAL DI LINGKUNAGN SEKOLAH}

Sebagaimana telah diterangkan bahwa pendidikan konservasi merupakan suatu program pendidikan yang bertujuan untuk menciptakan peserta didik yang menjunjung tinggi nilai-nilai sosial-budaya, maka pendidikan koservasi khususnya dalam dunia pendidikan formal merupakan suatu upaya untuk meningkatkan pengetahuan dan pemahaman peserta didik mengenai pentingnya nilai-nilai. Adapun nilainilai yang dimaksud, seperti nilai moral, nilai religi, nilai budaya, termasuk nilai-nilai pendidikan itu sendiri.

Dalam perkembangan mutakhirnya, pendidikan konservasi di sekolah-sekolah khususnya di Indonesia, bukan lagi hanya sebatas memberi materi melalui ceramah di dalam ruang kelas, akan tetapi dengan metode visual di luar ruang kelas pun telah diterapkan. Demikian, maka di sana mural (lukisan dinding) mengambil peran aktifnya sebagai media pembelajaran. Melalui mural di sekolah-sekolah, pendidikan konservasi tampil sebagai sesuatu yang berbeda dari yang sebelumnya.

Mural sebagai bentuk karya seni rupa yang representatif dan sarat dengan unsur-unsur komunikasi, hidup dalam lingkungan sekolah pada beberapa dekeade terakhir. Mural sering dijadikan sarana yang efektif dalam pendidikan konservasi di sekolah, yaitu sebagai model pembelajaran dengan metode visual. Hal ini, sesuai dengan pandangan Jon Prosser (2007), yang merumuskan suatu model pembelajaran di sekolah dengan metode visual. Prosser mengatakan:

... itu merupakan hal yang penting, karena mencerminkan kekuatan implisit kuat yang membentuk kegiatan sehari-hari, dan juga menyediakan dasar pemikiran metodologis untuk studi tema yang menyeluruh dalam pendidikan... Berfokus pada arsitektur sekolah, ruang nonmengajar... Tujuan yang mendasarinya adalah untuk mengatasi masalah yang berasal dari keistimewaan kata-kata lisan dan tertulis yang berbahaya dalam pembelajaran serta dalam penelitian kuantitatif dan kualitatif.

Mural sebagai sarana pendidikan konservasi di sekolah-sekolah, memang disarankan agar para murid atau peserta didik ketika melihat lukisan dinding yang dibuat, selain menjadi 'terhibur', sekaligus mendapatkan pesan-pesan dari lukisan dinding atau mural yang dilihatnya. Demikian, karena pembuatan mural di lingkungan sekolah, memang tidak hanya memikirkan unsur estetiknya saja, melainkan, dan yang paling utama adalah kandungankandungan pesan yang ingin disampaikan kepada peserta didik melalui mural tersebut. Dengan demikian, boleh dikata mural dalam lingkungan sekolah menjadi penting dan sangat mendidik.

Tidak jarang ditemukan mural di lingkungan sekolah dengan pesan-pesan yang hanya berupa tulisan-tulisan formal saja (grafity). Metode seperti ini, kini dianggap kurang efektif, karena hanya berupa tulisan saja sehingga kurang mendapat perhatian dari murid. Dengan demikian, maka tidak heran saat ini ketika kita memasuki beberapa lingkungan sekolah, kita akan melihat beberapa lukisan yang terpajang di dinding-dinding gedung sekolah, seolah-olah ada suatu kegiatan pameran lukisan yang diadakan dalam lingkungan sekolah itu. Padahal, ini merupakan metode yang baru dalam konteks pendidikan konservasi melalui metode visual, yaitu mural (Yeni, 2009:72).

Ada banyak pesan yang ingin dikomunikasikan kepada murid melalui mural dalam lingkungan sekolah, terutama pesan-pesan akan pentingnya menjunjung tinggi nilai-nilai moral (etika). Sebagai contoh, sebuah lukisan yang menggambarkan beberapa anak yang saling berpegangan tangan; anak-anak yang sedang bermain dan belajar bersama; seorang anak yang 
Suherman, S., Sunarto, S., dan Anggraeni, Sri Prastiti Kusuma

MURAL DI LINGKUNGAN SEKOLAH DALAM KONTEKS PENDIDIKAN KONSERVASI

REFLEKSI EDUKATIKA : Jurnal Ilmiah Kependidikan, Volume 9, Nomor 2, Juni 2019, hlm 192-203

mencium tangan orang tua dan gurunya; seorang anak yang sedang menolong temannya yang terjatuh; yang kesemuanya iyu dapat meningkatkan kepekaan dan kesadaran murid terhadap pentingnya nilai-nilai moral itu
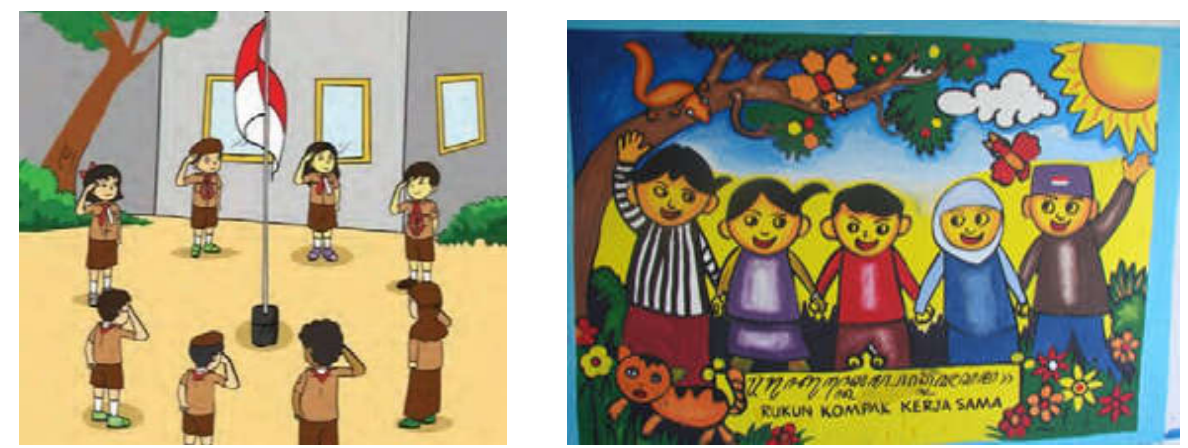

Gambar 5. Mural di sekolah yang mengandung nilai moral (etika) Sumber: Google.com, diakses 2019.

Selain itu, mural di dalam lingkungan sekolah juga sering mengandung pesan-pesan terkait nilai religious (keagamaan). Dalam hal ini, dapat diberikan contoh misalnya dalam meningkatkan nilai islami, seperti: lukisan dinding yang menggambarkan anak-anak yang sedang menuju tempat beribadah atau mesjid; anak-anak santri yang sedang belajar mengaji; suasana bulan suci ramadhan; objek-objek seperti manusia yang lengkap dengan kostum peribadatannya; hingga lukisan dinding yang menggambarkan suasana orang-orang yang sedang melaksanakan ibadah sholat.
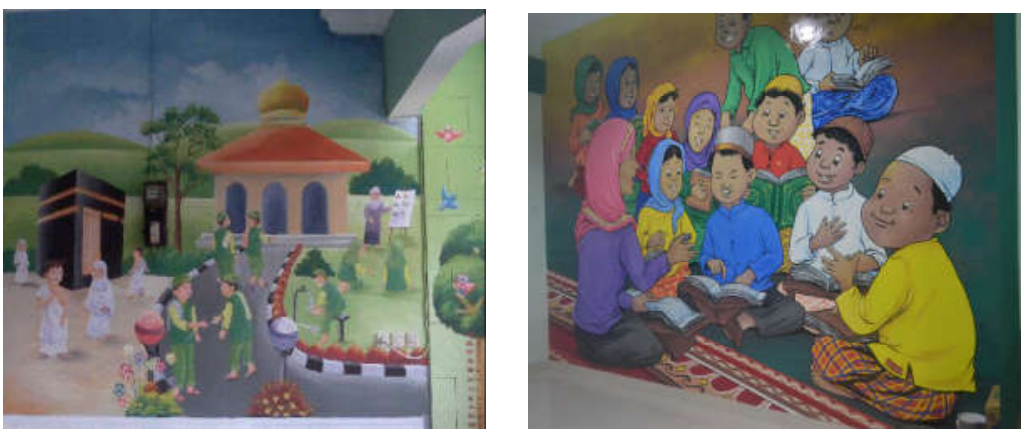

Gambar 6. Mural di sekolah yang mengandung nilai religi Sumber: Google.com, diakses 2019.

Adapun mural dalam lingkungan sekolah yang mengandung nilai-nilai budaya, dapat berupa: lukisan yang menggambarkan orang yang sedang memainkan alat musik tradisional, seperti gamelan (Jawa), sinrili' (Makassar) atau alat musik tradisional lainnya; orang-orang yang mengenakan baju adat; anak-anak yang sedang bermain permainan tradisional; hingga, gambargambar yang menampilkan benda-benda pusaka atau bangunan-bangunan, seperti candi-candi dan rumah-rumah adat. 

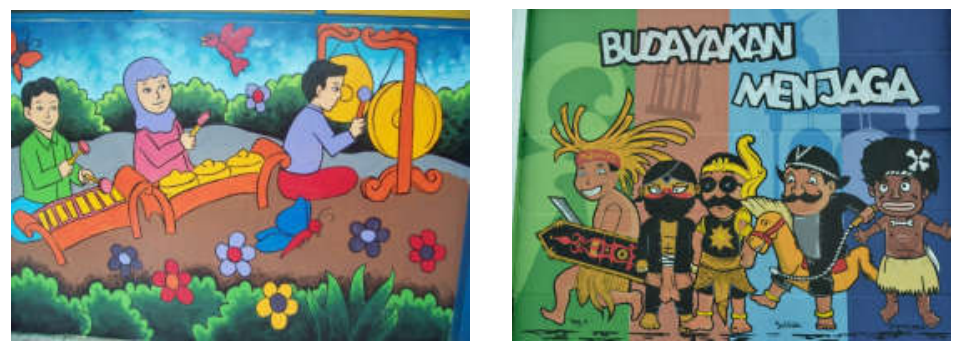

Gambar 7. Mural di sekolah yang mengandung nilai budaya Sumber: Google.com, diakses 2019.

Selanjutnya, mengenai pesan yang ingin dikomunikasikan melalui mural dalam lingkungan sekolah yang mengandung nilai-nilai pendidikan, dapat dilihat berupa: lukisan dinding yang menggambarkan anak yang sedang membaca buku; proses belajar mengajar di dalam atau di luar ruang kelas; anak yang sedang membuang sampah di tong sampah; hingga, suasana-suasana yang menunjukkan pentingnya menjaga kelestarian lingkungan sekitar, seperti menyiram tanaman, menanam pohon, menyapu halaman, dan membersihkan ruang kelas

Dari beberapa contoh di atas, dapat dikatakan bahwa mural di dalam lingkungan sekolah merupakan salah satu model pembelajaran dengan metode visual estetis yang digunakan dalam rangka menanamkan dan melestarikan nilai-nilai sosial-budaya. Demikian, karena berangkat dari suatu keyakinan bahwa, ketika murid atau peserta didik melihat lukisanlukisan yang dibuat di dinding sekolah, akan lebih mudah untuk menarik perhatiannya, dan mereka lebih mudah pula untuk mengaplikasikannya karena tinggal meniru apa yang dilihat dalam lukisan-lukisan tersebut (Sunarto, 2017).
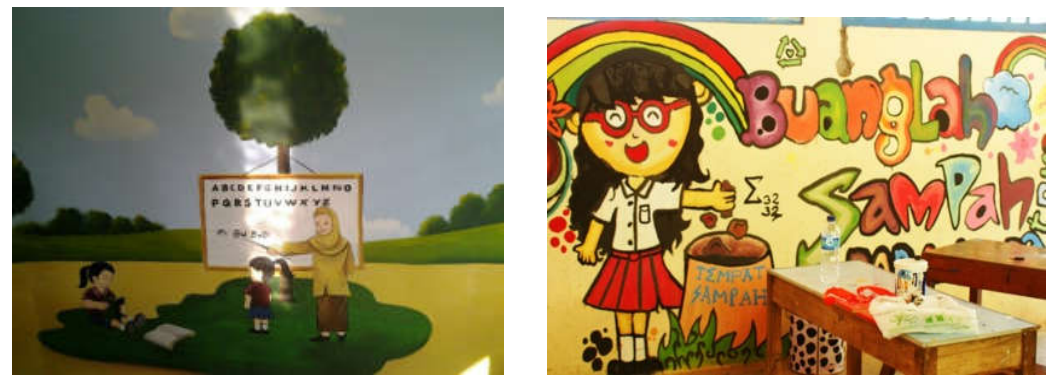

Gambar 8. Mural di sekolah yang mengandung nilai pendidikan Sumber: Google.com, diakses 2019.
Perlu digarisbawahi di sini bahwa bentuk visual mural di lingkungan sekolah harus disesuaikan dengan perkembangan usia peserta didik. Dalam hal ini berkaitan dengan perkembangan kemampuan intelektual, kepekaan rasa (estetik), dan pertumbuhan fisik perserta didik itu sendiri. Hal tersebut penting, agar peserta didik mampu mencerap atau menangkap pesan-pesan yang hendak disampaikan dalam lukisan dinding atau mural yang dibuat.

Di samping itu, pesan-pesan yang ingin disampaikan pun perlu diperhatikan. Dengan kata lain, pesan-pesan yang ingin disampaikan dalam lukisan dinding di lingkungan sekolah juga harus disesuaikan dengan perkembangan peserta didik. Misalnya, untuk lukisan-lukisan di sekolah TK, maka pesan-pesan yang disampaikan juga lebih bersifat sederhana, mudah dicerna oleh anak-anak TK, dengan bentuk visual berupa gambar kartun atau karikatur. Begitupun dengan sekolah-sekolah pada tingkat selanjutnya, baik pada tingkat SD, SMP, dan SMA, yang semuanya harus disesuaikan dengan kemampuan pencerapannya masing-masing. 
Suherman, S., Sunarto, S., dan Anggraeni, Sri Prastiti Kusuma

MURAL DI LINGKUNGAN SEKOLAH DALAM KONTEKS PENDIDIKAN KONSERVASI

REFLEKSI EDUKATIKA : Jurnal Ilmiah Kependidikan, Volume 9, Nomor 2, Juni 2019, hlm 192-203

SIMPULAN persoalan itu. Pada posisi ini, optimisme muncul dari para pemikir-pemikir pendidikan dengan merumuskan suatu program pendidikan yaitu pendidikan konservasi.

Pendidikan konservasi merupakan suatu program pendidikan yang menggunakan konsep konservasi sebagai sarana, paradigma, serta menjadi suatu ideologi khusunya dalam praktikpraktik pendidikan. Pendidikan konservasi dilakukan dalam rangka menanamkan serta melestarikan nilai-nilai luhur dan universal, yang dianggap telah mapan dan teruji oleh sejarah. Oleh karena itu, pendidikan konservasi dianggap sebagai salah satu alternatif atas kasus yang melanda dunia pendidikan dewasa ini, yang telah kehilangan perannya untuk membentuk karakter bangsa. Pendidikan konservasi merupakan pendidikan yang menanamkan dan melestarikan nilai-nilai adiluhung yang dianggap sebagai pedoman bagi manusia sebagai makhluk individu yang hidup dalam suatu kelompok sosial masyarakat.

Pendidikan kosnservasi khususnya dalam dunia pendidikan formal merupakan suatu upaya untuk meningkatkan pemahaman dan pengetahuan peserta didik mengenai pentingnya nilai-nilai, baik itu nilai moral (etika), nilai religi (agama), dan nilai budaya, serta nilai-nilai pendidikan itu sendiri. dalam perkembangan mutakhirnya, pendidikan konservasi bukan lagi hanya dilakukan dalam ruang kelas secara lisan dan tulisan. Akan tetapi pendidikan konservasi kini juga telah dipraktikkan diluar kelas, dengan menerapkan model pembelajaran dengan metode visual (gambar atau lukisan). Di sini, mural mengambil peran aktifnya sebagai media pendidikan dan pembelajaran.

Mural sebagai bentuk karya seni rupa yang representatif dan komunikatif, hidup dalam lingkungan sekolah sebagai media atau sarana pendidikan konservasi. Mural menjadi penting dan sangat mendidik, oleh karena pembuatan mural di sekolah-sekolah memang tidak hanya memikirkan unsur estetiknya saja, melainkan, dan yang paling utama adalah kandungankandungan pesan yang ingin disampaikan kepada peserta didik melalui mural tersebut. Dengan demikian, maka para peserta didik ketika melihat lukisan dinding yang dibuat, selain menjadi terhibur, juga sekaligus mendapatkan pesan-pesan dari lukisan mural ngayasngsidill ibathayya masyarakat, baik dalam lingkungan keluarga, sekola Di sisi lain, dengan menampilkan lukisan-lukisan dinding dalam lingkungan sekolah, juga merupakan suatu proses transformasi yang sifatnya lebih praktis dan mendidik. Oleh karna itu, mural yang di buat di dalam lingkungan sekolah akan memberi dasardasar pendidikan sikap dan keterampilan dasar kepada peserta didik, seperti, sopan santun, etika, kasih sayang, mengetahui serta menaati peraturan-peraturan, menanamkan kebiasaankebiasaan, dengan melihat dan meniru apa yang ada pada lukisan, sebab sikap dasar anak adalah suka meniru.

\section{DAFTAR PUSTAKA}

Buckley, William F., "Konservatisme dan Kenyataan Modern”. dalam Paulo Freire, (et, al.), 2015, Menggugat Pendidikan: Fundamentalis, Konservatif, liberal dan Anarkis, Yogyakarta: Pustaka Pelajar.

Dewantara, Ki Hadjar, 1977, Pendidikan: Pemikiran, Konsepsi, Keteladanan, dan Sikap Merdeka, Yogyakarta: Majelis Luhur Persatuan Taman Siswa.

Dewey, John, 2004, Eksperience and Education: Pendidikan Berbasis Pengalaman, diterjemahkan oleh Hani'ah, Bandung: Teraju.

Freire, Paulo, 2007, Politik Pendidikan: Kebudayaan, Kekuasaan dan Pembebasan (terjemahan). Yogyakarta: $\mathrm{REaD}$ dan Pustaka Pelajar.

Gandhi HW, Teguh Wangsa, 2011, Filsafat Pendidikan: Mazhab-Mazhab Filsafat Pendidikan. Yogyakarta: AR-RUZZ MEDIA.

Hardiman, Budi, 2003, Melampaui Positivisme dan Modernitas: Diskursus Filosofis tentang Metode Ilmiah dan Problem Modernitas. Yogyakarta: Kanisius.

Kesuma, Dharma, dkk, 2011, Pendidikan Karakter: Kajian Teori dan Praktik di Sekolah, Bandung: PT Remaja Rosdakarya. 
Suherman, S., Sunarto, S., dan Anggraeni, Sri Prastiti Kusuma

MURAL DI LINGKUNGAN SEKOLAH DALAM KONTEKS PENDIDIKAN KONSERVASI

REFLEKSI EDUKATIKA : Jurnal Ilmiah Kependidikan, Volume 9, Nomor 2, Juni 2019, hlm 192-203

Luthfi, Muhammad, 2014, "Sejarah Seni LukisLukisan Dinding (Mural)", http://www.kompasiana.com/Fianca97, diakses oktober 2016.

Masrukhi dan Margaretha Rahayuningsih, 2010, Universitas Konservasi: Wahana Pembangun Karakter Bangsa (Sebuah Renungan Dies Natalies Unnes ke-45). Semarang: Unnes.

O’Neil, William F, 2008, Ideologi-Ideologi Pendidikan. Yogyakarta: Pustaka Pelajar.

Pengelola MB-RAI dan Tim, "Konservasi Biodiversitas Raja 4: Lindungi Ragam, Lestari Indonesia", dalam Jurnal Informasi Status, Kondisi dan Berita Biodiversitas Indonesia, Vol. 4, No. 6, Juni 2015.

Piliang, Yasraf Amir, 2002, Identitas dan Budaya Massa: Aspek-Aspek Visual di Indonesia (Prolog), Yogyakarta: Yayasan Seni Cemeti.

Prosser, Jon, "Visual Methods and the visual culture of school, visual studies", dalam Journal of Arts and Humanities in higher education, 22 (1).

Rachman, Maman, "Konservasi Nilai dan Warisan Budaya", Indonesian Journal of Conservation (IJC), 1 (1): 30-39.

Richmond, Alison and Alison Bracker. 2009. Conservation: Principles, Dilemmasand Uncomfortable Truths. London: Victoria and Albert Museum London.

Soehardjo, A. J, 2012, Pendidikan Seni: Dari Konsep Sampai Program. Malang: Universits Negeri Malang.

Suherman, "Pendidikan Seni dan Penyadaran", dalam Tribun Opini (koran Tribun Timur), 7 April 2016.
Sunarto. 2016. "Antara Ilmu Pengetahuan dan Kepentingan menurut Jurgen Habermas", dalam Esai-Esai Pendidikan dan Seni. Semarang: Belum diterbitkan.

Sunarto. 2016. "Pragmatisme John Dewey (1859-1952) dan Sumbangannya terhadap Dunia Pendidikan”, Proceedings International Seminar Faculty of Education (FoE), Volume 1, Mei 2016, Fakultas Ilmu Pendidikan, Fakultas Pendidikan Teknologi dan Kejuruan, IKIP PGRI Madiun, hal. 150-165.

Sunarto. 2017. "Estetika dalam Konteks Pendidikan Seni". Refleksi Edukatika: Jurnal Ilmiah Kependidikan, 7 (2) : 102110.

Wicandra, Obed Bima. 2005. "Berkomunikasi Secara Visual melalui Mural di Yoyakarta", Journal NIRMANA, 7 (2): 126-133.

Yuniawan, Tommi, dkk. 2014. "Kajian Ekolinguistik Sikap Mahasiswa terhadap Ungkapan Pelestarian Lingkungan di Universitas Negeri Semarang”, Indonesian Journal of Conservation (IJC), 3 (1): 41-49.

Yeni R., Ida, Safitri Afriani F., dan Diyan Fatimatuz Zahra. 2018 "Seni Mural sebagai Media Pendidikan guna Mencegah Vandalisme di SMA Negeri Yogykarta", PELITA: Jurnal Penelitian Mahasiwa, IV (1): 71-80.

www.google.com

www.kbbi.online.com

https://www.makassarguide.com/2014/09/tamanprasejarah-leang-leang.html

https://www.diegorivera.org/man-at-thecrossroads.jsp

http://www.jean-michel-basquiat.org/hollywoodafricans/ 